\title{
Water stewardship and North America's food and beverage companies: a case study in corporate sustainability
}

\section{Peter Jones* and Daphne Comfort}

The Business School, University of Gloucestershire, The Park, Cheltenham, GL 50 2RH, UK

Email: pjones@glos.ac.uk

Email: dcomfort1@glos.ac.uk

*Corresponding author

\section{David Hillier}

Centre for Police Sciences,

University of South Wales,

Pontypridd, Wales, CF 37 1DL, UK

Email: illier@outlook.com

\begin{abstract}
The aim of this paper is to provide an exploratory review of the extent to which the leading North American food and beverage companies are publicly addressing water stewardship. The findings reveal that the vast majority of the selected companies address a number of elements concerning water stewardship as part of their more general approach to CSR. However, corporate commitments to water stewardship can be interpreted as being driven as much by business imperatives as by any specific concerns for CSR or a fundamental desire to maintain the viability and integrity of natural ecosystems. More critically the authors suggest that the selected companies' commitments to water stewardship are framed within existing business models focused on technological improvements in eco-efficiency and continuing economic growth.
\end{abstract}

Keywords: corporate social responsibility; CSR; sustainability; technology; water stewardship; food and beverage companies; North America.

Reference to this paper should be made as follows: Jones, P., Comfort, D. and Hillier, D. (2016) 'Water stewardship and North America's food and beverage companies: a case study in corporate sustainability', Int. J. Corporate Strategy and Social Responsibility, Vol. 1, No. 1, pp.26-43.

Biographical notes: Peter Jones works in the Business School at the University of Gloucestershire and his current research interests are in sustainability and water stewardship.

Daphne Comfort works in the Business School at the University of Gloucestershire and her current research interests are in sustainability and water stewardship. 
David Hillier is an Emeritus Professor in the Centre for Police Sciences at the University of South Wales and he has research interests in corporate social responsibility.

\section{Introduction}

The natural resources on which business corporations rely are becoming ever more difficult and costly to access. In reviewing the "business environment" in a "more complex and fast-moving world", KPMG $(2012$, p.10) argues that "shortages of a number of key resources are becoming apparent" and suggests that "companies in all sectors need to prepare themselves for a world where raw materials may be in short supply and subject to price volatility including large prices and increased disruption to supplies". At the same time, KPMG (2012, p.iii) suggests that "consumer and investor values are changing" and that "as they change more corporations are recognising that there is profit and opportunity in a broader sense of responsibility beyond the next quarter's results" and that "the bold, visionary and innovative recognise that what is good for people and the planet will also be good for the long term bottom line and shareholder value". These dynamic and potentially unpredictable changes in the availability of natural resources and changing consumer and investor values are becoming an increasingly important element in the complex relationship between corporations and society and as such they are looming as increasingly important element within corporate social responsibility (CSR) agendas.

In identifying the 'top sustainable business trends of 2014', Makower (2014, p.13) suggests that "companies, communities and countries are coming to recognize that water is increasingly being paired with the words crisis or risk". In identifying "water scarcity" as one of "ten global sustainability megaforces" that it "believes will impact every business over the next two decades", KPMG (2012) claims "businesses may well be vulnerable to water shortages, declines in water quality, water price volatility and to reputational challenges" and that "growth could be compromised and conflicts over water supplies may create a security risk to business operations". More specifically, Lambooy (2011, p.856) suggests that "water stress is increasingly viewed as a potential constraint on economic growth" and argues that "it can be considered part of CSR to adopt policies on sustainable water use".

Water is a major element within the food and beverage industry's supply chain though there are variations in the ways it is used across this sector. Within the agricultural sector it is an essential raw material for plant growth, in animal production and for irrigation. It is a primary, and often the major, ingredient for many products and within the food processing and manufacturing industries it is used in cleaning, boiling, cooling, pasteurisation, fermentation, dilution, retrieval, blanching, brining, to trigger germination and for the conditioning and transport of raw materials. At the same time water quality is a major consideration within the food and beverage industry and many food and beverage companies increasingly need to address a wide range of waste water treatment issues. In acknowledging that water is "a vital resource" for the food and beverage industry the 
UK's Institute for Grocery Distribution (IGD) argued that "the combination of limited availability and high demand, including the expected impacts of climate change, means food companies are subject to increasing water-related risks" and more pointedly has asked if "water scarcity" is "the biggest threat to global food security" (IGD, 2012). With this in mind this paper offers an exploratory review of the extent to which the leading players in food and beverage industry in North America is publicly reporting on water stewardship. The paper includes a brief introduction to the characteristics of CSR which provides a wider (conceptual) framework for the paper and an outline of the growing importance of water stewardship, a description of the framework for the review and the method of enquiry, an exploration of the various water stewardship issues reported by the top 20 foods and beverage processors in North America and some wider reflections on water stewardship within the food and beverage industry.

\section{Corporate social responsibility}

In simple terms CSR is concerned with the relationship between corporations and the societies with which they interact but operationally it is a complex and contested concept. Garriga and Mele (2004, p.51) argued CSR presents "a proliferation of approaches, which are controversial, complex and unclear" and Piercy and Lane (2009, p.335) suggest that a "precise definition of corporate social responsibility is problematic". That said a range of definitions have been proposed. Werner and Chandler (2011, p.3), for example, define CSR as "a view of the corporation and its role in society that assumes a responsibility among firms to pursue goals in addition to profit maximization and a responsibility among a firm's stakeholders to hold the firm accountable for its actions". Godfrey and Hatch (2007, p.87) suggest that CSR is rooted in the idea that "corporations have obligations to society that extend beyond mere profit-making activities" while for Brown and Dacin (1997, p.68) "corporate social responsibility associations reflect the organisation's status and activities with respect to its perceived societal obligations". More practically CSR is seen to be "related to complex issues such as environmental protection, human resource management, health and safety at work, relations with local communities, and relations with suppliers and consumers" [Branco and Rodrigues, (2006), p.111].

Although CSR has undoubtedly gained increasing momentum across the business community during the past decade it is important to recognise that the underlying concept has a long history. Hopkins and Crowe (2003), for example, suggest that there has always been a tension between business and social goals and they cite the power of the craft guilds in the Middle Ages, the slave trade and the struggles to improve living and working conditions in Britain's rapidly growing towns and cities during the nineteenth century, as graphic examples of these tensions. Sadler $(2004, \mathrm{p} .853)$ has argued that "the definition of the functions of the corporation with relation to wider social and moral obligations began to take place in the centres of capitalist development in the 19th century". 
A variety of factors are cited as being important in building the current momentum behind CSR. Porter and Kramer (2006, p.79), for example, argue that there are "four prevailing justifications for CSR" namely "moral obligation, sustainability, license to operate and reputation". The moral argument is that companies have a duty to be good citizens while the notion of license to operate recognises the fact that companies require explicit or at least tacit approval from various stakeholders in order to operate. A focus on reputation is rooted in the conviction that CSR commitments and achievements will help to improve a company's image and strengthen its brands while sustainability looks to emphasise environmental and community stewardship. Marketing is also providing a strong impetus for the increasing interest in CSR. Girod and Michael (2003, p.1), for example, have argued that CSR is "a key tool to create, develop and sustain differential brand names", Middlemiss (2003, p.353) has suggested that "CSR is taking centre stage to provide more sustainable, long term brand value" and Piercy and Lane (2009, p.335) has argued that "CSR is increasingly recognised as a source of competitive advantage".

The business case for CSR is seen to focus on a wide range of potential benefits. These include improved financial performance and profitability; reduced operating costs; long-term sustainability for companies and their employees; increased staff commitment and involvement; enhanced capacity to innovate; good relations with governments and communities; better risk and crisis management; enhanced reputation and brand value; and the development of closer links with customers and greater awareness of their needs and expectations. At the same time there are those who would champion the case against companies integrating CSR into their core business. Henderson (2001, p.32), for example, has argued that growing business commitment to CSR is "deeply flawed" in that "it rests on a mistaken view of issues and events and its general adoption by business would reduce welfare and undermine the market economy". More generally, Kitchin (2003, p.312) argues that CSR is "too narrow to engage management attention, too broad and unquantifiable to be taken seriously by the financial community and just woolly enough to be exploited by charlatans and opportunists".

The three dominant theories that have been used to analyse and explain CSR have been succinctly summarised by Moir (2001). Stakeholder theory suggests that it makes sound business sense for companies to understand the needs and aspirations of all their stakeholders be they investors, governments, employees, communities, customers or suppliers and that these needs and aspirations should be reflected in corporate strategy. Social Contracts theory asserts that companies may pursue CSR not because it is in their commercial interests but because it is how society expects companies to operate. Legitimacy theory stresses that society grants power to businesses and it expects them to use such power in a responsible manner.

\section{Water stewardship}

The growing pressure on freshwater resources in many areas of the world is throwing the issues of water allocation and water rights into increasingly sharp relief. The World Wildlife Fund (2007, p.8) argued such pressures are leading to "water stress, with serious negative impacts on social and economic development and the deteriorating health of aquatic ecosystems" and suggested that when "such water stress is reached, a new and more sophisticated approach to water management is required" and that "effective water management mechanisms need to be developed that manage the use of scarce resources". 
Paul Simpson the Chief Executive Officer of CDP, a global not-for-profit environmental organisation, for example, argued "the economic effects of mismanaging water resources are becoming increasingly apparent" and that this "will limit economic development" [CDP, (2013), p.4]. Over two decades ago Weinberg et al. (1993, p.278) suggested that "water use decisions are generally governed by historically determined prices and allotments rather than markets" and argued that "the inefficiencies of these water allocation mechanisms is well documented".

In identifying a wide range of water management problems, Kidd and Shaw (2007, p.312) argued that integrated water resource management "has emerged as the dominant paradigm for tackling these concerns". Integrated water resource management is defined as "a process which promotes the coordinated development and management of water, land and related resources in order to maximise economic and social welfare in an equitable manner without compromising the sustainability of vital ecosystems" (Global Water Partnership, 2012). However, Hepworth and Orr (2013, p.220) identified the emergence of "corporate water stewardship" as a "new paradigm" in water resource management. Corporate water stewardship is seen to be differentiated from integrated water resource management in that while the former is about "private actors increasingly involving themselves in the management of the common pool-public good regarding water" the latter involves "actions by an authority mandated by the state (within which ownership of the resource is vested by law) to manage water resources on behalf of all water users" [Hepworth and Orr, (2013), p.222].

Basically stewardship is an ethic that embodies the responsible planning and management of resources. Environmental stewardship concerns the responsible use and protection of the natural environment through conservation and sustainable practices and this responsibility is shared by all those whose actions affect the environment. Hickle and Stitzhal (2003, p.1) argued that "the limits of traditional regulatory approaches in addressing environmental problems, combined with a sharpened focus on the environmental impacts and the growing role of corporate-led environmental initiatives, have fuelled a growing international trend towards product stewardship". Further, Hickle and Stitzhal (2003, p.2) suggest that "while all stakeholders in the product chain - including retailers, consumers and government share some responsibility for life-cycle impacts, product stewardship assigns greater responsibility to manufacturers because they have the greater ability to reduce the environmental impact of their products".

Water stewardship is basically concerned with the responsible management and future planning of water resources and it is rooted in the belief that all water users have a role to play in the sustainable management of the earth's freshwater resources. However there seems to be no agreed definition of water stewardship and in part it is a contested concept. The Alliance of Water Stewardship (2013, p.4) defined water stewardship as "the use of water that is socially equitable, environmentally sustainable and economically beneficial, achieved through stakeholder-inclusive process that involves site and catchment based activities". More specifically corporate water stewardship "allows companies to clarify and manage water related business risks" (Pacific Institute, 2014) and the World Wildlife Fund $(2013$, p.1) has defined "water stewardship for business" as "a progression of increased improvements of water use and a reduction in the water related impacts of internal and value chain operations". 
The Pacific Institute (2014) suggested that "companies around the world increasingly recognise the risks that water scarcity, pollution and weak water governance have on their core business" and that "they are beginning to acknowledge the need to manage water as a key input in production and better address the ways in which their water use and waste water discharge can affect nearby ecosystems and communities". In outlining water stewardship as an increasingly important issue for businesses, CDP (2013, p.13) argued that "companies with robust water stewardship strategies are typically characterised by having a comprehensive knowledge of water use across their value chain and the impact (current and projected) that water related issues have on their business and vice versa. More importantly, they have appropriate plans and procedures in place to mitigate risks that give adequate consideration to priorities of the local watershed in which they operate". Looking to the future Paul Simpson, the Chief Executive Officer of CDP, argued that "investors and companies that understand the complexities of water and devise and implement a strategy that drives water stewardship will be the long term winners in an increasingly water stressed world" [CDP, (2013), p.4].

\section{Frame of reference and method of enquiry}

In an attempt to obtain a preliminary picture of the extent to which food and beverage industry is publicly addressing water stewardship as part of their CSR reporting, the top 20 food and beverage companies in North America in 2013, as ranked by Food Processing (2014) were selected for study (see Table 1). The companies vary considerably in the scale, nature and diversity of their business operations and in their geographical reach and many are household names. PepsiCo, for example, is a leading global food and beverage company with operations in over 200 countries, a net revenue of 65 billion US\$ in 2012 and a product portfolio that includes Pepsi-Cola, Seven Up, Aquafina, Tropicana, Quaker Oats, Doritos and Fritos. Tyson Foods produces a variety of chicken, pork and beef products and processed foods, it employs some 115,000 people at a large number of production facilities, feed mills, tanneries and hatcheries in the USA and overseas and works with over 6,000 independent chicken farmers and supplies customers throughout the USA and in over 130 countries. MillerCoors is the second largest beer company in the USA accounting for almost $30 \%$ of the country's beer sales, it operates eight major breweries within the USA and its portfolio includes the premium light brands Coors Light and Millers Lite as well as Coors Banquet, Miller Genuine Draft and Miller High Life. Hershey is the largest producer of quality chocolate in the USA and it markets and sells a range of chocolate and sugar confectionery in some 70 countries. Overall the selected companies might be seen to reflect cutting edge approaches to water stewardship within the food and beverage industry and to be keen to publicise their water stewardship commitments and achievements to a wide and diverse audience. As such the selected companies provide a basic but suitable framework to explore the extent to which large companies are addressing water stewardship and as such they might be expected to reflect cutting edge thinking and practice within the food and beverage industry. 
Table 1 Water stewardship

\begin{tabular}{l} 
Top 20 food and beverage companies in North America \\
\hline PepsiCo http://www.pepsico.com/ \\
Tyson Foods http://www.tyson.com/ \\
Nestle http://www.nestle.com/ \\
JBS http://www.jbssa.com/ \\
Anheuser-Busch http://www.ab-inbev.com/ \\
Kraft Foods http://www.kraftfoodsgroup.com/home/index.aspx \\
General Mills http://www.generalmills.com/ \\
Smithfield Foods http://www.smithfieldfoods.com/ \\
Dean Foods http://www.deanfoods.com/ \\
Mars http://www.mars.com/global/index.aspx \\
Coca-Cola http://www.mars.com/global/index.aspx \\
ConAgra Foods http://www.mars.com/global/index.aspx \\
Kellogg's http://www.kelloggcompany.com/en_US/home.html \\
Cargill http://www.kelloggcompany.com/en_US/home.html \\
Hormel Foods http://www.kelloggcompany.com/en_US/home.html \\
MillerCoors http://www.kelloggcompany.com/en_US/home.html \\
Pilgrim's Pride http://www.pilgrims.com/ \\
Unilever http://www.unilever.com/ \\
Mondelez International http://www.mondelezinternational.com/ \\
Hershey http://www.mondelezinternational.com/
\end{tabular}

Source: Adapted from Food Processing's Top 100 Food Processing

Companies use a wide variety of platforms to communicate and report on environmental commitments and programmes and the European Commission Directorate-General for Enterprise lists a number of methods that businesses currently utilise including "product labels, packaging, press/media relations, newsletters, issue related events, reports, posters, flyers, leaflets, brochures, websites, advertisements, information packs and word-of mouth" (European Commission Directorate-General for Enterprise undated, webpage). During recent years "the importance of online communications as part of an integrated CSR communications strategy has grown significantly" (CSR Europe, 2009) and sustainability reporting "is now undeniably a mainstream business practice worldwide" (KPMG, 2013). With this in mind the authors undertook an internet search for material on water stewardship on each of the selected company's corporate websites (see Table 1) in April 2014 using the key words 'CSR report' and employing Google as the search engine.

The precise patterns of search inevitably varied from one company to another but the information revealed by this search procedure provided the empirical material for this paper. The specific examples and selected quotations from the selected corporate websites within this paper are used primarily for illustrative purposes and there is no attempt to provide a systematic analysis or comparative evaluation of the ways companies are addressing water stewardship. Rather the focus is singularly on conducting an exploratory examination of how water stewardship is currently being addressed, 
conceptualised, operationalised and packaged for public consumption within the North American food and beverage industry. That said the authors recognise that this approach has its limitations in that there are issues in the extent to which a company's public statements realistically, and in detail, reflect current strategic corporate thinking on water stewardship and whether or not such pronouncements are little more than thoughtfully constructed public relations exercises. However, given the need to drive forward exploratory research in this increasingly important area for businesses and to begin to understand the extent to which major companies are addressing water stewardship as part of their CSR strategies the authors believe that the internet-based approach adopted in this paper offers an appropriate entry point for analysis and a readily accessible pool of data to underpin the current study. In discussing the reliability and validity of information obtained from the internet, Saunders et al. (2009) emphasise the importance of the authority and reputation of the source and the citing of a contact individual who can be approached for additional information. In surveying the selected companies the authors were confident that these two conditions were met.

\section{Findings}

The internet search revealed that 16 of the selected companies, namely PepsiCo, Tyson Foods, Nestle, Anheuser Busch, General Mills, Smithfield Foods, Mars, Coca-Cola, Conagra Foods, Kellogg's, Cargill, MillerCoors, Pilgrim's Pride, Unilever, Mendelez and Hershey posted sustainability reports which included specific material on water stewardship. Three companies, namely JBS, Dean Foods and Hormel provided varied but more limited information on their approach to water stewardship and there was no information on water stewardship posted on Kraft Food's corporate website. Within the sustainability reports and information there was considerable variation in both the nature and the volume of the information provided but a range of water stewardship issues were addressed, albeit in different measure and under different headings, including water stewardship strategy; water footprinting; efficiency and reduction in water use; water conservation and recycling; employee engagement; water risks; water resource management; water in the supply chain; and community engagement. While a minority of the companies look to publicly report on a wide range of issues, the majority adopt a narrower focus on what they perceive to be the major issues.

A small number of companies explicitly stress both the strategic importance of water to their business and their corporate commitment to water stewardship. Nestle, for example, claims "a long history of leadership on water stewardship because it is critical to the future success of our business and our value chain". More specifically the company reports the launch of the 'Nestle Commitment on Water Stewardship' in 2013 which embraces five key commitments namely to "work to achieve water efficiency"; "advocate for effective water policies and stewardship"; "treat the water we discharge effectively"; "engage with suppliers especially those in agriculture" and to "raise awareness of water access and conservation". More generally Smithfield Foods claims that "sustainability has permeated our entire company and that it is important to all our stakeholders including our investors". Anheuser Busch reports that "high quality water is critical to our products and central to many of the processes we use to produce them" and Coca Cola emphasises its corporate commitment to water stewardship stating "Inside every bottle of Coca-Cola is the story of a company that understands the priceless value of 
water, respects it as the most precious of shared global resources and works vigorously to conserve water worldwide".

In some of the selected companies, water footprinting is seen as an important element in underpinning and informing water stewardship strategy. A company's water footprint is simply defined as the total volume of freshwater used to produce a company's goods and services. Unilever, for example, reports on conducting "detailed measurement and analysis of our water footprint to inform our strategy". This analysis revealed that some of the company's product categories are more water intensive than others and potentially yield the major opportunities, for example, for water reduction. More specifically in 2012, for example, Unilever calculated the water required to produce a range of agricultural products and identified tomatoes and sugar as its key crops and a number of specific locations where water reduction programmes could have the greatest impact.

Programmes and Initiatives designed to reduce the volume, and to improve the efficiency, of water consumption against set targets are reported by the majority of the selected companies. Dean Foods stresses that "understanding how we use water is at the heart of our water conservation efforts, which include both reducing water usage and finding ways to return clean water to ecosystems". More specifically the company reports its employment of water audits to identify, measure and record water use and to identify best practice for asset protection and improved efficiency. The company further reports that this auditing process has led to the identification of over 250 individual water efficiency projects across its operations. Looking to the future the company's goal is to achieve a $35 \%$ reduction in the intensity of water use (namely the volume of water per unit of production) by 2020 . Hormel provides a number of specific examples to illustrate its attempts to reduce water consumption including the introduction of new spray nozzles in its smokehouse ovens at Austin, Minnesota which reduce water usage by almost 50\% and the installation of a new blanching process at Dubuque, Iowa which reduced annual water usage by almost 6 million gallons.

Kellogg's reports a range of water saving initiatives including the installation of a reverse osmosis system at its manufacturing plant in Manchester UK in 2013 and the replacement of manual washing by an automated washing process at the company's cereal plant at Charmhaven in Australia which reduced water usage by $90 \%$. By way of a further illustration of its water reduction initiatives Kellogg's Corporate Social Responsibility Report also included a mini case study of its Georgia factory in Rome, Italy. The company reports that this production facility employs some 50 hoses and nozzles to clean the sticky conveyor belts with high pressure streams of water which, when in operation, each uses some 45 litres of water per minute. The company reports that it has introduced and installed a new more efficient conveyor belt washing system which has reduced the water used per hose to less than 14 litres per minute. Overall Kellogg's reports that the changes outlined above along with improvements to heating and sanitation systems within the factory have led to a reduction its water usage per tonne of food produced by $69 \%$ during 2012.

Commentaries on reductions in water use are often also linked to wastewater treatment and recycling. Coca-Cola, for example, claims that "in addition to improving our water efficiency, we are also reducing our impact on water systems and contributing to improved water quality by appropriately treating wastewater and returning it to the environment". Coca-Cola reports that all its company owned production plants worldwide are compliant with local wastewater treatment regulations and standards though it recognises the challenges involved in attempting to ensure that independent 
bottling plants in some 200 countries are similarly compliant. Tyson Foods stresses its commitment "to protecting the water bodies that we discharge to" and the company reports on operating some 34 full treatment and another 43 pre-treatment wastewater facilities in North America and that its long term aim "is to eliminate notices of violation and permit exceedances related to the operation of these facilities". More specifically it reports reducing the former by $86 \%$ and the latter by $48 \%$ during the period $2010-2012$.

The role of employee engagement in water stewardship is emphasised by some of the selected companies. MillerCoors, for example, stresses that "our employees drove great progress in reducing our water usage in 2012" and the company reports that monitoring brewery performance in real time at frequent intervals during each work shift not only enables brewery managers to directly encourage employees to be constantly alert to water usage but also helped to identify changes to improve the efficiency of water use. In a similar vein Nestle suggests that "by continuing to engage our people with the national and local water stewardship agenda, they can see the issues first hand and prioritise opportunities for shared value with our suppliers, partners and stakeholders". Nestle also reports on its investment in its training and education programme for employees, which "enables them to make better informed decisions that lead to effective water stewardship" and which "fosters a systematic, employees-involved, continuous improvement culture". A mini case study of improvements in water efficiency at Nestlé's confectionery factory at La Penilla in Spain concludes "the project has also improved awareness of water stewardship among our employees, creating positive behavioural change for the long term".

The issues of physical and regulatory risk and water conservation measures designed to mitigate such risks are explicitly addressed by some of the selected companies. Physical risk concerns the availability and quality of water while regulatory risk is bound up with what is often increasing strict government legislation and regulations on water allocation and pricing, wastewater treatment and the issue of operating licenses. ConAgra Foods, for example, explicitly recognises that managing physical water risk is critical to its continuing business success and that the nature of such risks can change dramatically over a short period of time. By way of an illustration of such changes ConAgra reports that during 2012 the company managed the risks associated with the major flooding of the Missouri and Mississippi Rivers in the central US when the flood waters were very close to its production facilities and affected the everyday lives of many of its employees. The following year the same area of the country faced a major drought which seriously damaged crop yields. Many of the leading food and beverage companies report on their regulatory compliance including, for example, action to ensure that extraction licenses are in place and that waste water discharges meet, and in some cases, exceeds statutory local standards.

In its sustainability report Smithfield Foods provided a mini case study on a major programme to help conserve aquifers in North Carolina. Here the company's slaughterhouse at Tar Heel, which opened in 1997, initially withdrew 2 million gallons of water each day from two local aquifers and while the area offers abundant water resources there is "a significant shortage of high-quality fresh water". In 1997, Smithfield Foods installed a 'water rescue system' designed to recycle over 1 million gallons of water per day which in turn allowed the company to increase production while reducing not only its water demands but also the volume of treated water being discharged into the local river system. JBS provided some brief illustrative pen pictures of its water conservation projects. The company's wholly owned Five Rivers feeding 
subsidiary, for example, recycles and reuses water in an attempt to extend "the life of underground aquifers and surface water resources" while the company reports that its beef processing division is "saving over 10 million gallons per week of water".

Coca-Cola reports requiring each of its 860 bottling plants to conduct local water source vulnerability assessments. The company also reports requiring a water source sustainability assessment as an integral part of the due diligence process when acquiring new land for a new factory or purchasing a business with existing manufacturing plants. Such assessments embrace the social, environmental and political risks to the water resources which will supply the production facilities and the local communities. They include a description of the water resources available to the plant for both water supply and waste treatment; a review of available water quality; an inventory of the local relevant water resource management agencies and their policy regulation and planning priorities; and an evaluation of how water use could limit both the availability and quality of water for local communities. These assessments provide the framework for bottling plants to develop and implement action plans for risk mitigation at the watershed level. Nestle reports its use of the 'Nestle Combined Water Stress Index' to assess water stress at given locations. This index helps the company to determine the risks associated with reduced water quantity or quality as well as risks from possible competition with other local users.

Looking beyond their own operations, some of the selected companies address water in the supply chain and the issue of community engagement. Nestle, for example, argues that "the greatest challenge to reduce our water consumption lies in addressing the impacts beyond our factories- in our complex supply chains". The scale of this challenge is enormous not only in that Nestle works directly with some 690,000 farmers but also in that the company's "sphere of influence touches millions more through the commodities we purchase". At the same time Nestle explicitly recognises that engaging with its diverse and geographically widespread supply chain is critical if the company is to meet its own water security and water stewardship goals. The 'Sustainable Agriculture Initiative at Nestle' is a global programme designed to support farmers and to address some of the major challenges in water management and irrigation including farmer and crop resilience to drought and flooding and wastewater and organic waste treatment. Kellogg's reports on its work with grain breeders and growers to improve water management and irrigation practices and to introduce more drought tolerant crop varieties while ConAgra's sustainable agriculture programme focuses upon reducing water use for crops where the company has a direct relationship with growers.

There are a number of strands to the theme of community engagement which operates at a variety of scales. Locally and as part of its broader sustainability commitments to 'People and Communities' MillerCoors reports on working with not for profit organisations and local volunteers to improve and preserve water resources in over 20 local communities where the company has production facilities. The company also reports on being a primary sponsor of the 'Water as a Crop' pilot project designed to implement conservation practices on privately owned land along the Trinity River in Texas. Here in an attempt to encourage voluntary conservation, farmers and ranchers receive financial reimbursement for watershed projects that manage water runoff, reduce soil erosion, improve water quality and enhance the economic viability of farms. MillerCoors reports that by the end of 2012 some 39 landowners had signed agreements to improve the management of over 16,000 acres of land. 
On a much wider scale Coca-Cola reports on its support for the United Nations Development Programme and more specifically on the 'Every Drop Matters' programme which has undertaken up to 100 projects embracing watershed restoration, sustainable agriculture initiatives and capacity building among government water managers in over 20 countries predominantly in the former Soviet Union. More generally Coca-Cola also reports on its initiatives in addressing the 'water-energy-food nexus' and in working towards the ambitious and challenging task of seeking to "ensure water, energy and food security for everyone". Here some projects are increasing the capacity of watersheds to absorb some of the threats associated with increasingly severe weather events while others are attempting to build resilience in response to ever increasing demands for water, energy and food. More generally Nestle reports on its approach to 'public policy engagement'. While the company believes that 'governments must take the lead to establish water policies that give people universal access to clean and safe water, within which Nestle and other water users can operate" it asserts its willingness to "assist in this process, by advocating for effective water policies and water stewardship".

\section{Discussion}

The findings suggest that the vast majority of North America's leading food and beverage companies address water stewardship as an integral part of their more general approach to CSR. Many of the selected companies also report on future plans to increase their drive for further water efficiency and to develop and/or enhance some of their existing initiatives on water stewardship. As such the findings would seem to support Makower's (2014) position that concerns about water are becoming an increasingly important element in CSR strategies. At the same time the findings reveal considerable variation in the information the leading North American food and beverage companies publicly provide on their approach to water stewardship. In part this would seem to reflect a number of factors including the importance the selected companies currently attach to water stewardship, their strategic corporate commitment to water stewardship, the resources they are prepared to commit to corporate sustainability reporting and the extent to which they want or feel it necessary to commit to the public disclosure of their water stewardship strategies, targets and achievements. While many of North America's food and beverage companies are, in reality, at the beginning of their water stewardship journey, a number of issues merit general discussion and reflection.

Firstly there is a set of issues concerning the ways in which the top 20 North American food and beverage companies report on their approach to water stewardship. Generally the accent is on providing a simple narrative of water stewardship initiatives and programmes, sometimes illustrated with basic descriptive statistics and mini case studies with pictures and simple diagrams being widely used to illustrate broad themes. Currently there are no clear, agreed or definitive international standards for water stewardship disclosure though some of the selected companies utilise water specific voluntary reporting frameworks including the CDP (formerly the Carbon Disclosure Project) Water Disclosure key indicators and the United Nation's CEO Water Mandate reporting template. While some of the selected companies, including Hershey's, PepsiCo and MillerCoors, claim their corporate sustainability reports reflect and/or comply with the Global Reporting Initiative (2007) guidelines others provide information on water stewardship in their own idiosyncratic house style. Overall the lack of common and 
agreed frameworks and standards and the use of simple case studies makes it difficult not only to make any meaningful comparisons between one company and another but also to assess the contribution that these companies are making towards water stewardship at regional, national and international levels.

At the same time there is little evidence of independent external assurance of the information on water stewardship posted on their corporate websites by the selected food and beverage companies. Unilever, for example, employed external auditors to undertake limited assurance of a number of the performance measures included in their sustainability report but water stewardship was not explicitly tackled in either of these assurance exercises. The widespread lack of independent external assurance can be seen to undermine the transparency, reliability and integrity of the sustainability information posted by the selected companies. That said it is important to remember that many of these companies are large, complex and dynamic organisations. Capturing and storing comprehensive information and data across a diverse range of business activities throughout the supply chain in a variety of geographical locations and then providing access to allow external assurance is a challenging and a potentially costly venture and one which many of the selected currently choose not to publicly pursue. In part this would seem to mirror the more general reflection that "supply chains area roadblock to improved performance" [Global Water Partnership, (2012), p.18] in improving corporate sustainability.

Secondly while there are variations in the ways in which North America's leading food and beverage companies have implicitly defined water stewardship, collectively their approach can be interpreted as being built around business efficiency and business continuity. The dominant concern, for example, is to reduce the volume, and improve the efficiency, of water consumption which not only helps to safeguard current and future operations but also to reduce costs. As such the water stewardship initiatives and programmes can be seen to be driven as much by business imperatives as by commitments to sustainability. In the opening message to Tyson Foods sustainability report, for example, Kevin Igli, the company's Chief Environmental Health and Safety Officer, argues "our focus on "People, Planet, Profit and Products" must be in line with our business practices and strategies, or the desired outcomes will simply not be achieved". More specifically Smithfield Foods water conservation programme outlined earlier in this paper which the company reported would "protect existing groundwater supply, reduce drought risk and provide the infrastructure needed to support future economic development" also allowed Smithfield Foods to increase production. In a similar vein a number of Coca-Cola's reported watershed projects in Illinois developed in partnership with the US Department of Agriculture, for example, supply water to the company's plants as well as to other local users.

More generally such an approach would seem to be consistent with the claim by Deloitte (2012) that companies develop sustainability issues "based upon what matters most to the business" and this would, in turn, seem to privilege commercial imperative in the construction and development of sustainability agendas. More critically, Banerjee (2008, p.51) has argued that "despite their emancipatory rhetoric, discourses of corporate citizenship, social responsibility and sustainability are defined by narrow business interests and serve to curtail the interests of external stakeholders". This, in turn, echoes Hobson's (2006, p.308) argument that rich and powerful groups will construct sustainability agendas that do not threaten consumption, per se, but seek to link them "to 
forms of knowledge - science, technology and efficiency - that embody the locus of power" already held by large business corporations.

Thirdly in their pursuit of efficiencies in water stewardship a number of North America's leading food and beverage companies have looked to harness technological innovation and to promote the diffusion of seemingly environmentally friendly technologies. PepsiCo, for example, reports on innovative solutions to conserving water at its food facility in Funza in Columbia. Here the company installed a high efficiency water reclamation system using a specialised membrane bioreactor which enables the reuse of $75 \%$ of the water entering the plant. This membrane bioreactor technology, combined with low-pressure reverse osmosis produces recycled water that meets the US Environment Protection Agency standards. More generally Nestle argues that its approach to sustainability involves, inter alia, "large investments in technology with lower environmental impact". However, Huesemann (2003, p.21) suggests a number of reasons "why technological improvements in eco-efficiency alone will be insufficient to bring about a transition to sustainability". Potentially more divisively, Vorosmarty et al. (2010, p.555) argue that "massive investment in water technology enables rich nations to offset high stressor levels without remedying their underlying causes, whereas less wealthy nations remain vulnerable". In extending this political argument, Schor (2005, p.310) has suggested that not only do "advocates of technological solutions argue that more intelligent design and technological innovation can dramatically reduce, or even stop the depletion of ecological resources" but also that "the popularity of technological solutions is also attributable to the fact that they are apolitical, and do not challenge macrostructures of production and consumption".

Fourthly there are issues about the nature of the relationship between CSR strategies and public sector policies in pursuing water stewardship and about the locus of power within this relationship. The United Nation's CEO Water Mandate (2014, p.2), for example, has noted that corporate strategies are "grounded in the premise that they advance the public interest and are mutually beneficial to companies, their stakeholders and other actors in the watershed" and that current concerns and perceptions about the growing incidence of water stress "offer a much greater incentive for companies to align their water-related policies and practices with the public interest than in the past". In a similar vein, Hepworth and Orr (2013, p.231) suggest that "for those who strive for greater user engagement in managing water, the rousing of the private sector represents breakthrough; releasing potential to influence society and the global economy towards more sustainable means of production and resource use". While Hepworth (2012, p.545) suggests that "as yet there is little evidence of whether corporate engagement is merely a cynical attempt by business to extend control over the resource" there are arguments that corporate water stewardship strategies privilege private interests over wider public interests. Hall and Lobina (2012, p.3), for example, argued that while a number of large corporate users of water "use the idea of water efficiency and reducing their global water footprint to claim that this is offsetting local impacts" but that "these measures do nothing to reduce the actual impact in these specific locations, and have to be understood as public relations exercises". Further, Hepworth (2012, p.553) argued that "a primary concern about corporate engagement on water from a social equity perspective is that multiple processes of capture will work to exclude or subdue other stakeholder views, resulting in policy that favours narrow vested interests to the detriment of the public good". More politically, Hepworth and Orr (2013, p.231) argue corporate water 
stewardship emphasises "capital's unique ability to appropriate and sublimate critiques against it and a threat to future water equity and justice".

Finally there are tensions between commitments to water stewardship as part of CSR strategies and the pursuit of continuing growth. Coca-Cola, for example, stresses that the company is "firmly committed to advancing our growth trajectory" while Nestle claims to be committed to 'sustainable growth' without explicitly defining the term. Corporate commitments to continuing growth are certainly consistent with the argument by Reisch et al. (2008, p.2), that while moving towards sustainability is a major policy agenda, "growth of income and material throughput by means of industrialisation and mass consumerism remains the basic aim of western democracy". There are also arguments that economic growth, dependent on the continuing depletion of the earth's finite natural resources, is incompatible with sustainability and that harnessing technology will not offer a realistic long term solution. Huesemann (2003, p.21), for example, claimed that business leaders have promoted the concept of eco-efficiency in order "to ensure that continued economic growth and environmental protection can go hand in hand" but argued that "improvements in eco-efficiency alone will not guarantee a reduction in the total environmental impact if economic growth is allowed to continue". Looking to the future, Huesemann (2003, p.21) further argued that unless growth in consumption is restrained "technological improvements only delay the onset of negative consequences that as a result, will have increased in severity, thereby reducing our freedom to choose satisfying solutions".

\section{Conclusions}

The findings of this exploratory study suggest that the majority of North America's leading food and beverage companies publicly address water stewardship as part of their wider approach to CSR. However, many of the reported water stewardship achievements and commitments can also can be interpreted as part of a wider search for operational efficiencies and cost reductions which are driven as much by business imperatives as by any ongoing commitment to the sustainability of natural ecosystems and resources. There is only limited evidence of any independent external assurance of the information the leading food and beverage companies provided on their water stewardship achievements and this in turn undermines the credibility, integrity and reliability of these reported achievements.

More critically, the authors suggest that the selected companies' commitments to water stewardship are couched within existing capitalist business models focused on technological improvements in eco-efficiency and continuing economic growth. Here concerns that "policy and regulatory capture that will prioritise water allocation for highest value economic value use over environmental and social well-being, livelihood, cultural values and functions, enabling the already powerful to buy out or capture the resource" [Hepworth and Orr, (2013), p.231] clearly resonate. Looking to the future in the short to medium term the leading players in the food and beverage industry may be well advised to provide more comprehensive and verifiable commentaries on their approach to water stewardship achievements and on their achievements in promoting socially equitable and environmentally beneficial outcomes within their CSR reports. More pessimistically, Schendler and Toffel (2013) have argued that "corporate sustainability is not sustainable" and in the longer term, and in the wake of potentially 
dramatic and unpredictable climate changes, existing business models may be inherently unsustainable. While this scenario poses major business continuity risks for the whole of the food and beverage industry such risks may in turn be dwarfed by greater and more daunting challenges facing humanity.

\section{References}

Alliance of Water Stewardship (2013) The AWS International Water Stewardship Standard [online] http://www.allianceforwaterstewardship.org/Beta\%20AWS\%20Standard\%2004_03_2013.pdf last (accessed 2 October 2014).

Banerjee, S.B. (2008) 'Corporate social responsibility: the good, the bad and the ugly', Critical Sociology, Vol. 34, No. 1, pp.51-79.

Branco, M.C. and Rodrigues, L.L. (2006) 'Corporate social responsibility and resource based perspectives', Journal of Business Ethics, Vol. 61, No. 2, pp.111-132.

Brown, T.J. and Dacin, P.A. (1997) 'The company and product: corporate associations and consumer product responses', Journal of Marketing, Vol. 61, No. 1, pp.68-84.

CDP (2013) From Water Management to Water Stewardship [online] https://www.cdp.net/ CDPResults/CDP-US-Water-Report-2013.pdf (accessed 2 October 2014).

CSR Europe (2009) Trends and Best Practice in Online Reporting CSR/Sustainability Reporting [online] http://ec.europa.eu/enterprise/policies/sustainable-business/corporate-socialresponsibility/reportingdisclosure/swedishpresidency/files/surveys and reports/trends and be st_practice_in_online_csr_and_sustainability_rep_en.pdf (accessed 25 February 2014).

Deloitte (2012) Going from Good to Great: Ways to Make Your Sustainability Report Business Critical [online] https://www.deloitte.com/view/en US/us/Services/additional-services/ sustainability-climate-change/8918785fc75b9310VgnVCM3000001c56f00aRCRD. htm?id=blog_sustainability_091912 (accessed 30 April 2014).

European Commission Directorate-General for Enterprise (undated), A Guide to Communicating about CSR [online] http://ec.europa.eu/enterprise/policies/sustainable-business/files/csrsme/communication_guide_en.pdf (accessed 21 March 2014).

Food Processing (2014) Food Processing's Top 100 [online] http://www.foodprocessing.com/ top100/top-100-2013/ (accessed 12 July 2014).

Garriga, E. and Mele, D. (2004) 'Corporate social responsibility theories: mapping the territory', Journal of Business Ethics, Vol. 53, Nos. 1-2, pp.51-71

Girod, S. and Michael, B. (2003) 'Branding in European retailing: a corporate social responsibility perspective', European Retail Digest, Vol. 38, No. 2, pp.1-6.

Global Reporting Initiative (2007) Sustainability Reporting 10 Years On [online] http://www.globalreporting.org/NR/rdonlyres/430EBB4E-9AAD-4CA1-9478FBE7862F5C23/0/Sustainability_Reporting_10years.pdf (accessed 25 February 2014).

Global Water Partnership (2012) What Is Integrated Water Resource Management? [online] http://www.gwp.org/The-Challenge/What-is-IWRM/ (accessed 20 October 2014).

Godfrey, P.C. and Hatch, N.W. (2007) 'Researching corporate social responsibility: an agenda for the 21 st century', Journal of Business Ethics, Vol. 70, No. 1, pp.87-98.

Hall, d. and Lobina, E. (2012) Conflicts, Companies, Human Rights and Water - A Critical Review of Local Corporate Practices and Global Corporate Initiatives, a Report for Public services International for the 6th World Water Forum at Marseilles, March [online] http://www.pseau.org/outils/ouvrages/psiru_conflicts_companies_human_rights_and_water_a critical_review_of_local_corporate_practices_and_global_corporate_initiatives_2012.pdf (accessed 2 September 2015).

Henderson, D. (2001) 'The case against corporate social responsibility', Policy, Vol. 17, No. 2, pp.28-32. 
Hepworth, N.D. (2012) 'Open for business or opening Pandora's box? A constructive critique of corporate engagement in water policy: an introduction', Water Alternatives, Vol. 5, No. 3, pp.543-562.

Hepworth, N.D. and Orr, S. (2013) 'Corporate water stewardship: new paradigms in private sector water engagement', in Lankford, B.A., Bakker, K., Zeitoun, M. and Conway, D. (Eds.): Water Security: Principles, Perspectives and Practice, Earthscan Publications, London.

Hickle, G.T. and Stitzhal, D. (2003) 'Apportioning responsibilities for product stewardship: a case for a new federal role', Environmental Quality, Vol. 12, No. 3, pp.1-16.

Hobson, K. (2006) 'Competing discourses of sustainable consumption: does the rationalisation of lifestyles' make sense', in Jackson, T. (Ed.): The Earthscan Reader in Sustainable Consumption, Earthscan, London.

Hopkins, M. and Crowe, R. (2003) Corporate Social Responsibility: Is there a Business Case? [online] http://www.accaglobal.com/pdfs/members_pdfs/publications/csr03.pdf (accessed 2 March 2015).

Huesemann, M.H. (2012) The Limits of Technological Solutions to Sustainable Development [online] http://dub.thayer.dartmouth.edu/ d30345d/courses/engs171/Limits-toSustainability.pdf (accessed 15 April 2014).

IGD (2012) Water Scarcity: The Biggest Threat to Global Food Security [online] http://www.igd.com/our-expertise/Sustainability/Water/4871/Water-scarcity-the-biggestthreat-to-global-food-security/ (accessed 2 October 2014).

Kidd, S. and Shaw, D. (2007) 'Integrated water resource management and institutional integration: realising the potential of spatial planning in England', The Geographical Journal, Vo. 173, No. 4, pp.312-329.

Kitchin, T. (2003) 'Corporate social responsibility: a brand explanation', The Journal of Brand Management, Vol. 10, Nos. 4-5, pp.312-326.

KPMG (2012) Expect the Unexpected: Building Business Value in a Changing World [online] http://www.kpmg.com/dutchcaribbean/en/Documents/KPMG\%20Expect_the_Unexpected_Ex ctveSmmry_FINAL_WebAccessible.pdf (accessed 23 April 2014).

KPMG (2013) The KPMG Survey of Corporate Responsibility Reporting [online] http://www.kpmg.com/Global/en/IssuesAndInsights/ArticlesPublications/corporateresponsibility/Documents/corporate-responsibility-reporting-survey-2013-exec-summary.pdf (accessed 23 April 2014).

Lambooy, T. (2011) 'Corporate social responsibility: sustainable water use', Journal of Cleaner Production, Vol. 19, No. 8, pp.852-866.

Makower, J. (2014) State of Green Business 2014 [online] http://www.greenbiz.com/research/ report/2014/01/19/state-green-business-report-2014?ms=45828 (accessed 23 April 2104).

Middlemiss, N. (2003) 'Authentic not cosmetic: CSR as brand enhancement', The Journal of Brand Management, Vol. 10, Nos. 4-5, pp.353-361.

Moir, L. (2001) 'What do we mean by corporate social responsibility?', Corporate Governance, Vol. 1, No. 2, pp.16-22.

Pacific Institute (2014) Corporate Water Stewardship [online] http://pacinst.org/issues/corporatewater-stewardship/ (accessed 20 October 2014).

Piercy, N.F. and Lane, N. (2009) 'Corporate social responsibility: impacts on strategic marketing and customer value', The Marketing Review, Vol. 8, No. 4, pp.335-360.

Porter, M.E. and Kramer, M.R. (2006) 'Strategy and society: the link between competitive advantage and social responsibility', Harvard Business Review, Vol. 84, No. 12, pp.78-92.

Reisch, L., Spash, C.L. and Bietz, S. (2008) Sustainable Consumption and Mass Communication: A German Experiment [online] http://www.csiro.au/files/files/pm9m.pdf (accessed 16 June 2013).

Sadler, D. (2004) 'Anti-corporate campaigning and corporate social responsibility: towards alternative spaces of citizenship?', Antipode, Vol. 36, No. 5, pp.851-869. 
Saunders, M., Lewis, P. and Thornhill, A. (2009) Research Methods for Business Students, Prentice-Hall, Harlow.

Schendler, A. and Toffel, M. (2013) Corporate Sustainability is Not Sustainable [online] http://grist.org/climate-energy/corporate-sustainability-is-not-sustainable/ (accessed 26 May 2015).

Schor, J.B. (2005) 'Prices and quantities: unsustainable consumption and the global economy', Ecological Economics, Vol. 55, pp.309-320 [online] http://www.sciencedirect.com/science/ article/pii/S0921800905003204\# (accessed 27 November 2013).

United Nation's CEO Water Mandate (2014) Shared Water Challenges and Interests: The Case for Private Sector Engagement in Water Policy and Management [online] $\mathrm{http} / / /$ ceowatermandate.org/files/private-sector-water-policy-engagement.pdf (accessed 2 October 2014).

Vorosmarty, C.J., McIntyre, P.B., Gessner, M.O., Dudgeon, D., Prusevich, P., Green, P., Gidden, S., Bunn, S.E., Sullivan, C.A., Reidy, Liermann, C. and Davies, P.M. (2010) 'Global threats to water security and river biodiversity', Nature, Vol. 467, No. 7315, pp.555-561.

Weinberg, M., Kling, C.L. and Wilen, J.E. (1993) 'Water markets and water quality', American Journal of Agricultural Economics, Vol. 75, No. 2, pp.278-291.

Werner, W. and Chandler, D.B. (2011) Strategic Corporate Social Responsibility, Sage, Thousand Oaks, California.

World Wildlife Fund (2007) Allocating Scarce Water [online] http://assets.wwf.org.uk/downloads/ allocating_scarce_water.pdf (accessed 25 May 2015).

World Wildlife Fund (2013) Water Stewardship: Perspectives on Business Risks and Responses to Water Challenges [online] http://awsassets.panda.org/downloads/ws_briefing_booklet_lr_ spreads.pdf (accessed 21 May 2014). 